\title{
List of Charts and Figures
}

Chart 1-West German Foreign Service Personnel 1951-55 127

Chart 2-West German Missions Abroad 1949-June 1955134

Chart 3-Percentage of Former NSDAP Members (Higher Service), 1950-54 169

Chart 4 -Summary of Biographical Information on 100 Leading Officials in the West German Foreign Office, September 1949-June 1955171

Chart 5-Percentage of Wilhelmstraße Veterans in the Higher Service, 1950-54 172

Fig. 1-The Auswärtiges Amt in the Wilhelmstraße, Berlin, around 193527

Fig. 2-Hans von Herwarth and Konrad Adenauer, $1952 \quad 67$

Fig. 3-The defendants at the Ministries Trial in Nuremberg, February $1948 \mathbf{8 1}$

Fig. 4 -Adenauer leaving Allied High Commission headquarters on September 21, 1949, after receiving the text of the Occupation Statute 103

Fig. 5-The new Foreign Office in the Koblenzer Straße (today Adenauerallee) in Bonn, September 12, 1955133

Fig. 6 - Illustration from a 1951 anonymous pamphlet satirizing the return of the veteran diplomats 155

Fig. 7-Albert Hilger van Scherpenberg and Ernst Mühlenhaupt, December 1959177

Fig. 8-Adenauer, Walter Hallstein, and Herbert Blankenhorn, October $1954 \quad 187$

Fig. 9-Political cartoon featuring Adenauer and Heinrich von Brentano, $1955 \quad 211$

Fig. 10 -Albrecht von Kessel 231 
